\title{
Analysis on the Construction of Nonferrous Metal Logistics Park in ZX City of Hunan Province
}

\author{
Shijun Yuan \\ Hunan Modern Logistics College \\ Changsha, China 410131
}

\author{
Jianhua Chen* \\ Hunan Modern Logistics College \\ Changsha, China 410131 \\ *Corresponding Author
}

\begin{abstract}
On the basis of in-depth analysis of the development status and trend of nonferrous resources in ZX City, Hunan Province, this paper further discusses the construction background, necessity and conditions of the project, and puts forward suggestions on the construction scale and content of the project.
\end{abstract}

\section{Keywords—nonferrous metals; logistics park; construction}

\section{INTRODUCTION}

ZX City, Hunan Province, has abundant nonferrous metal resources. In order to further promote the development of nonferrous metal industry in the region, the construction of nonferrous metal logistics park is guided by the government and led by the enterprises.

\section{DEVELOPMENT STATUS AND TREND OF NONFERROUS METAL MARKET IN CHENZHOU AND ZX CITY}

\section{A. Overview of Nonferrous Metals in Chenzhou}

Chenzhou's mineral resources are world-famous for their variety and huge reserves. There are 110 kinds of minerals that have been discovered, and 70 types classified in 7 categories of minerals that has been proved, with a potential value of more than RMB 260 billion. Chenzhou is regarded as the "home of nonferrous metals in China" and "world nonferrous metals museum". The reserves of both tungsten and bismuth rank first in the world, and reserves of tin and zinc rank the third and the fourth respectively in China. Other mineral resources are also extremely rich, and the microcrystalline graphite is rare in the world, with reserves of more than 36 million tons. Fluorite reserves are over 68 million tons, accounting for $76 \%$ of the country's total associated fluorite reserves.

After decades of development and construction, nonferrous metal industry in Chenzhou has formed an industrial production system that has preliminarily complete supporting procedures, such as, geological prospecting, mining, mineral processing, smelting and processing, and has become one of the six major pillar industries in this city. Chenzhou has become a main nonferrous metal production base in China. Driven by scientific and technological progress and institutional innovation, the nonferrous metal industry in Chenzhou will take a new industrialization road, and regard the comprehensive utilization of nonferrous metals, and development of industrial chain economy and high-tech economy as the main content, so as to realize the leap-forward development of nonferrous metals and build a worldrenowned industrialization base.

Currently, Chenzhou is actively establishing a guarantee system for nonferrous metal resources, implementing the strategy of scale upgrading and technology leading, and preparing to build a nonferrous metal futures delivery warehouse and a nonferrous metal trade fair. Chenzhou strives to continuously enhance its own voice on nonferrous metal resource market, and hopes to build itself into a national "demonstration zone" for scientific development and utilization of nonferrous metal resources, a "gathering zone" for characteristic nonferrous metal industries, a "pilot zone" for technological innovation in the field of nonferrous metals, and a "leading zone" for the trading market of non-ferrous metal products, technologies and equipment.

As a resource city which is called "home of nonferrous metals in China", when facing financial crisis, Chenzhou has proposed to transform itself into "China's nonferrous metal capital" on the basis of industrial upgrading and restructuring.

\section{B. Overview of Nonferrous Metal Industry in ZX City}

ZX City, located in the east of Chenzhou, is famous for its lead zinc ore in Qingjiang River, tungsten ore in Qingshi, alluvial gold deposit in Dongping and scheelite in Chukou.

Along with the development of mining industry and mushroom growth of nonferrous metal smelting industry, the following enterprises are located in the Jiangbei industrial parks of ZX City: Huaxin Nonferrous Metals Co., Ltd., Project Enterprise Nonferrous Metals Co., Ltd., Fengyue Smelting Plant, etc. Nonferrous metal smelting will become an important added value for ZX City's GDP, and a number of enterprises will jointly build nonferrous metal smelting bases.

Based on the above-mentioned data and adjustment of industrial structure and market changes, the production for nonferrous metal smelting in $\mathrm{ZX}$ is predicted as follows:

First, it has increased steadily and is different in structure The global problem of energy shortage will facilitate the price increase of raw materials. As the profits of the real economy decline, some investors will become speculators. With the increasing virtual economy, the output of nonferrous metals decreases and the production value increases. Therefore, the 
metal smelting industry in ZX City will maintain a steady and increasing trend.

Second, the development of manufacturing industry has increased the demand for nonferrous metals. Due to the shortage of energy, the world's demand for nonferrous metals has increased. The main reason is: substitute raw materials are undeveloped, and the arms race is slowly rising. In the wave of rising prices, Chenzhou will expand the mining of nonferrous minerals, and the raw materials channels in smelting industry will be multifaceted.

\section{OVERVIEW OF LOGISTICS IN CHENZHOU AND ZX CITY}

In recent years, although the logistics industry in ZX City and Chenzhou has been developed, it still stays in the traditional and spontaneous logistics stage. Whether the organizational structure, the way of operation, or the economic and social benefits, its conditions are far from the requirements and goals of modern logistics. The main problems are as follows:

\section{A. The Basic Logistics Conditions Are Still Weak}

The united transportation system of railways and highways in the territory has just started, without air transport. The construction of logistics supporting facilities is obviously lagging behind, and a convenient and efficient threedimensional transportation system with wide radiation range has not been formed. The logistics and storage facilities are seriously inadequate, and the level of mechanization of shipment is too low and does not get rid of the original mode of manual loading and unloading, and the construction of logistics network informatization has not started yet, which restricts the performance of logistics function and the improvement of logistics efficiency.

\section{B. The Cost of Logistics Is High, and the Business Model and Intensive Degree of Logistics Enterprises Needs to Be Improved}

Generally, the proportion of logistics cost to GDP is regarded as an important index to measure logistics efficiency and benefit internationally. After implementing modern logistics, this index in developed countries and regions has been controlled at about $10 \%$ (10.5\% in the United States, $11.4 \%$ in Japan, $13.1 \%$ in Taiwan, $13.9 \%$ in Singapore and $13.7 \%$ in Hong Kong). According to the statistical data analysis in recent years, the logistics cost of the whole Chenzhou city is $19.4 \%$ of GDP, and the logistics cost of ZX city is $19.6 \%$ of GDP, and their logistics cost is twice those of developed countries. Generally speaking, the current business model of most logistics enterprises in ZX City and Chenzhou is still in a relatively extensive and junior stage. It shows unformed modern logistics concept, weak enterprise service capacity, low intensive degree, and quality and benefits to be improved.

\section{There Are Some Difficulties in the Development of the Third Party Logistics Enterprises}

The third party logistics refers to a kind of logistics operation and control method that in order to do a good job in main business, production and operation enterprises entrust the logistics activities originally handled by themselves to the professional logistics service enterprises by contract, and maintain close contact with the logistics service enterprises through the information system in the meantime, so as to control and manage the whole process of logistics. Self-run logistics in the enterprise has its convenience, but it is uneconomic from the perspective of the whole society. The waste of logistics resources is serious, and the logistics facilities are unreasonable. Based on the survey on major supermarkets in Chenzhou, most of them have signed contracts with suppliers, and suppliers directly deliver goods, which is high cost, low efficiency and not intensive enough.

\section{The Reform of Logistics Management System Needs to Be Further Deepened, and Logistics Resources Need to Be Further Integrated}

The long planned economy makes the logistics industry lag behind in ZX and Chenzhou. In the process of transforming from planned economy to market economy, the reform of management system lags behind the reform of economic system due to the influence of traditional concepts. Similar to the situation of the national logistics industry, logistics industry in Chenzhou is still a decentralized or diversified management mode, which has caused problems such as fragmentation and separation of departments in the management of logistics industry. Most logistics construction projects are to expand supply capacity, rather than to integrate and upgrade the original supply capacity, and the projects in low level are the same and account high range, but some projects pursue the large scale and pursue perfect, resulting in over capacity and the waste of logistics resources. From the perspective of network platform, information platform cannot be co-constructed and shared, which restricts the development of logistics industry, and makes the logistics industry in the state of separate administration and social information impeded. This undoubtedly creates obstacles for the modern logistics industry with information flow as its soul.

\section{E. Capital Shortage}

Due to the huge investment in many logistics projects and long investment return cycle, the investment risks are relatively high, and it is difficult for the enterprise itself to raise enough funds. For example, a logistics center project needs a total investment of RMB 119.04 million, and the enterprise has raised funds of RMB 63.58 million by itself and applied for RMB 40 million of medium and long-term loans for the construction of rural circulation system to the business department of China Agricultural Development Bank Chenzhou Branch. It has signed a loan contract of RMB 20 million, with a total of RMB 6 million in place, and the project funding gap is about RMB 20 million. Lack of funds has become a bottleneck hindering the development of logistics enterprises in ZX City and Chenzhou.

\section{CONSTRUCTION BACKGROUND AND NECESSITY OF THE PROJECT}

Chenzhou is the capital of nonferrous metals in China, and located in the southeast of Hunan Province, Jiangxi to the east, Guangdong to the south. It enjoys a superior geographical position and developed transportation, and is a distribution center for nonferrous metals. 
At present, Chenzhou has achieved remarkable results in resource integration. Relying on the deep processing of mineral products to extend the industrial chain, four concentrated areas for intensive processing of mineral products, including Chenzhou nonferrous metal industrial park, have been established. Moreover, a number of countylevel concentrated areas for intensive processing of mineral products are also developing rapidly, gradually forming a mineral resource development pattern with close connection among municipal nonferrous metal industrial park, countylevel mineral products processing park, large mining companies, and mining enterprises. However, the construction of logistics supporting facilities in Chenzhou city lags behind, and the logistics and warehousing facilities of nonferrous metals are seriously inadequate.

To this end, as required by Nonferrous Metals Industry Adjustment and Revitalization Plan and Logistics Industry Restructuring and Revitalization Plan, based on the current situation of logistics industry in Chenzhou City and development trend of the nonferrous metal industry, the construction of this project is in line with the trend.

\section{CONSTRUCTION CONDITIONS}

ZX City is located in the southeast of Hunan Province, east of Bozhou City, upstream of Leishui, and south of Luoxiao Mountains. Its geographic position is $25^{\circ} 34^{\prime}-26^{\circ} 18^{\prime}$ north latitude, $113^{\circ} 08^{\prime}-113^{\circ} 44^{\prime}$ east longitude.

ZX City is the frontier of Hunan docking Guangdong, Hong Kong and Macao, with convenient transportation and smooth communication. In terms of railway, Chensan railway is connected to Jingguang railway. In terms of highways, the provincial highway 1813 and Chenzi high-grade highway are connected with national highway 106 and 107 and Jingzhu highway. The communication network covers all urban and rural areas. The provincial-level economic development zone is equipped with food industrial parks, Jiangbei Industrial Park and "the three-processing and one compensation" base. It is an ideal place for businessmen from home and abroad to make invest and purchase houses.

The project site is located at the place of low mountains and hills. The stratum is mainly dolomitic limestone. It belongs to the karst-based limestone dissolution landform and has good karst development. The original surface soil is backfill and planting soil. The substratum under the ground belongs to quaternary cover, mainly composed of soft plastic clay and hard plastic clay. Thicker plastic medium compressive heavy sub-clay is distributed along the ditch.

The construction side has not yet provided the geological survey report for the site. Through on-site inspection and investigation, the construction situation of other construction projects in the area where the site is located shows that there is no unfavorable geology in the site, and no adverse geological phenomena such as active faults and landslides and liquefiable soil layers are found in the site. The site is stable, and the groundwater is mainly pore phreatic water in the upper loose soil layer, which has no corruption effect on the building and is suitable for engineering construction.
According to Seismic Ground Motion Parameter Zonation Map of China (GB18306- 2001) issued by State Bureau of Quality Technical Supervision in February 2001, the ground motion peak acceleration in this area is $0.05 \mathrm{~g}$, and the period of seismic response spectrum is $0.35 \mathrm{~s}$.

\section{CONTENT AND SCALE OF CONSTRUCTION}

\section{A. Construction Content}

According to the current warehousing situation of enterprises, lead reserves account for $80 \%$, and silver reserves account for $15 \%$, and reserves of other precious metals account for $5 \%$. Lead reserves will increase, because the lead reserves in Chenzhou rank first in the world. In the early two years, the supply of raw materials for enterprises was limited to the surrounding counties of ZX City, but the business was expanded to Zhejiang, Shanghai, Guangdong, Shenzhen and other places, so the production capacity could not meet the market demand. According to the production scale of project enterprises and industrial base of ZX City and Chenzhou city, as well as the demand and circulation of nonferrous metals throughout the country, it can be preliminarily predicted that the annual logistics quantity of the project is 5 million tons, of which the annual trans-shipment cargo volume is 2.4 million tons and the annual warehousing turnover volume is 2.6 million tons (Among them, the annual warehousing turnover volume of raw materials, lead and zinc, and precious nonferrous metals including silver is 1.6 million tons, 0.8 million tons and 0.2 million tons respectively.).

\section{B. Content of Construction}

The project construction is divided into the following four functional areas: business office area, logistics information service area, third-party logistics area, and comprehensive living service area.

Business office area:

It is composed of business office building, walking plaza and green space parking lot.

Logistics information service area:

It consists of logistics information service center, walking plaza and green space parking lot; the logistics information service center has 200 logistics information service trading seats.

\section{Third party logistics area:}

It consists of warehouse, LTL logistics transaction shop front, testing center, management room and lounge, and truck parking lot.

\section{Comprehensive living service area}

It is composed of auto repair workshop, canteen, staff quarters, power distribution room, pump room and fire pool.

The park road is arranged in a grid pattern with three eastwest main roads and two north-south main roads. As each functional area has its own nature, three entrances and exits are set up on the urban road near the west side to orderly arrange the traffic of logistics base in the park, and they are 
respectively connected to three east-west main roads in the base.

\section{CONCLUSION}

The construction of the industry logistics center project first needs to be established in the logistics needs of the development of the industry. On the basis of fully considering the industrial development in the area covered by the project, in light of the regional industry competition and the characteristics of industry products, the construction scale and construction content will be scientifically and rationally designed.

\section{REFERENCES}

[1] Han Xingwei. Exploration on Logistics Operation Mode of Nonferrous Metals [J]. China Metal Bulletin. 2003. 4.

[2] Zeng Qingbao. Expanding Demand for Logistics in Nonferrous Industry. China Finance and Economic News. 2013-01-29.

[3] Huang Guanli. Thoughts on the Establishment of Logistics Center by Daye Nonferrous Metals Group Holding Co., Ltd. [J]. China Metal Bulletin. 2010. 26. 